\title{
Tūtira mai! Reporting a Tiriti o Waitangi settlement ceremony for public radio through a Māori lens
}

\begin{abstract}
Radio New Zealand is a Government-owned public broadcaster in Aotearoa New Zealand. Its news channel, RNZ National, has among its reporting team Māori journalists who report in English on issues of significance to Māori for a national audience that is predominantly non-Māori. This case study documents the activities of a bilingual Māori RNZ National reporter as she covers a Tiriti o Waitangi settlement between the Crown and a collective of East Coast iwi (tribes). It traces how the reporter balances tikanga, or Māori cultural norms, with journalistic demands as she produces news stories for the internet and radio and images for Twitter. The news content is presented and analysed through the lens of the Anglo-American news values in operation in Aotearoa New Zealand, demonstrating how Māori history, culture and aspiration are centred within these. This paper assumes some understanding of news values and journalistic practice and process.
\end{abstract}


Keywords: Māori journalism; journalism practice; newsgathering; ethnography in newswork; tikanga; te reo Māori.

\section{Introduction}

Māori are ethnically Polynesian and migrated in waves from the northern Pacific Ocean from 1300AD. They brought with them collectivist values and a highly developed oral culture organised around whakapapa, a word that refers to genealogical descent but also to the belief that everything in the natural and spiritual worlds is related and interdependent (Walter \& Reilly, 2018). The visit of British admiral Captain James Cook on the Endeavour in 1769 was followed by an influx of sealers, whalers, traders, missionaries and settlers from, predominantly, the United Kingdom (Anderson et al., 2014). Māori named the new arrivals Pākehā, a name derived from the indigenous word for mythical, pale-skinned beings (Ranford, 2015).

As a nation-state, Aotearoa New Zealand is founded on Te Tiriti o Waitangi (the Treaty of Waitangi), ${ }^{1}$ a partnership agreement signed in 1840 between Māori and the British Crown. Breaches by the Crown were almost instant, resulting in land confiscation and war. However, recent decades have

\footnotetext{
1 This paper uses the name Te Tiriti o Waitangi to distinguish between the reo-Maori version of the document, which the majority of chiefs understood and signed, rather than the problematic English version. For more on differences between the two and how this has affected the Crown-Māori relationship, see The Treaty of Waitangi Te Tiriti o Waitangi: An illustrated history by Claudia Orange (Bridget Williams Books, 2021).
} 
seen concerted efforts to redress the damage colonisation wrought on Māori language, culture and wellbeing, primarily through the Waitangi Tribunal, established in 1975 to investigate historical and ongoing breaches of Te Tiriti and recommend redress (Anderson et al., 2014).

Te Tiriti o Waitangi settlements are important events in public life and are staple news in Aotearoa New Zealand for both mainstream and Māori-language media. As of January 2021, a total of 96 deeds of settlement had been signed between the Crown and claimant groups, collectively worth some $\$ 2.6$ billion (M. Chen, personal communication, January 18, 2022).

Public bodies are expected to reflect the principles of partnership, participation and protection enshrined in Te Tiriti (Network Waitangi Ōtautahi, 2018), and among these is Radio New Zealand (RNZ), a taxpayer-funded, independent, publicservice radio broadcaster that is the most trusted of the country's major news brands (Myllylahti \& Treadwell, 2020). RNZ's charter requires it to reflect, among other things, the country's "cultural identity, including Māori language and culture" (The Radio New Zealand Charter, n.d.).

At present, in a country of 4.9 million, Māori number $16.5 \%$ of the population and Pākehā $70.2 \%$ (Stats NZ, 2020). Increasingly, all New Zealanders are embracing Maori culture, with one survey finding that $73 \%$ of non-Māori and $70 \%$ of Māori agreed that Māori culture was part of everyone's heritage (Te Puni Kōkiri, 2018).

However, colonisation has wreaked great damage on te reo Māori, and revitalisation of the language is a joint Crown-iwi responsibility. At the 2013 Census, 148,400 people could hold a basic conversation in 
te reo, $84.5 \%$ of whom identified as Māori. The Government has set a goal that one million New Zealanders will speak at least basic reo by 2040 (Te Puni Kōkiri, 2018).

The news arm of Radio New Zealand, RNZ National, recruits Māori journalists to provide the public with a Māori perspective, and these reporters are both bilingual and monolingual. Although they report in English only, reporters' use of greetings and simple sentences in te reo on air plays a key role in supporting the national agenda to revitalise te reo Māori, in which normalisation of te reo in public life is a critical plank (Te Puni Kōkiri, 2018).

We can trace the sustained use of Māori words and phrases in RNZ newswork back to 2016, the year the station formulated a policy to help it meet its obligations to language and culture (Thompson, 2016). In the run-up to the annual awarenessraising Māori Language Week in July that year, two senior reporters, Shannon Haunui-Thompson, who is the subject of this case study, and colleague Mihingaarangi Forbes suggested that reporters across the organisation might sign off their stories in te reo. They were encouraged to say, "This is (name)", which can be rendered as "Ko (name) ahau" or "Ko (name) tenei" (Middleton, 2020b).

A number of reporting staff, both speakers and nonspeakers of te reo, did so. After the week ended, senior managers encouraged reporters to continue, and many have (you can see a list of the phrases RNZ reporters and presenters use here). Other major news shows have followed suit, particularly Television New Zealand's flagship news programme, 1 News, and the news operation of Three, called Newshub. 


\section{Methodology and method}

The context for this paper is the day-to-day practice of indigenous-minority journalists working within national media, a field that has had limited academic attention. Several papers have explored the influence of indigenous culture on newswork overseas (Markelin, 2017; Pietikäinen, 2008; Skogerbø et al., 2019) and Aotearoa New Zealand (Hanusch, 2013). However, they rely, problematically, on reporter self-assessment, which raises the risk of desirability bias (Bryman, 2012; Davidson \& Tolich, 2003; Pugh, 2013). In Aotearoa New Zealand, observational studies of indigenous newswork are limited to those in Middleton (2020a). The research question is this: How does a Māori reporter working for a mainstream news service centre the indigenous perspective on an event while clearly communicating to a national audience?

The overall paradigm informing this paper is kaupapa Māori, a paradigm for enquiry by, for and with Māori that centres a Māori worldview and indigenous ways of seeing, being and doing (Irwin, 1994; Smith, 2012). However, the approach does not ignore the realities of Māori lifeways in a colonised country. Kaupapa Māori research

weaves in and out of Māori cultural beliefs and values; western ways of knowing, Māori histories and experiences under colonialism, western forms of education, Māori aspirations and socio-economic needs, and western economies and global politics (Smith, 2012, p. 193).

As the above may suggest, Māori journalists and kaupapa Māori researchers like the writer are "necessarily bicultural" (Holmes, 2003, p. 133), 
moving between mainstream and indigenous worlds.

This paper takes a case-study approach (Creswell, 2013) in its observation of an indigenous journalist as she reports on a Tiriti o Waitangi settlement. A weakness of case studies that they capture one moment in time, so we need to be cautious about making generalisations. However, the strength of case studies lies in their ability to provide a rich and in-depth look at the dynamics of the phenomenon under investigation (Flyvbjerg, 2006).

Here, we gain insight into how a Māori perspective can be reflected in mainstream media. This is particularly important for journalism students and practising journalists, as there is little Māori or bicultural content in journalism education in Aotearoa New Zealand and few Māori journalism students (Whelan, 2021). Among a largely Pākehā news media, there are gaps in knowledge of the Māori world (Adds et al., 2005).

The author is a news ethnographer (Cottle, 2000, 2007) who uses a small digital camera to film reporters at work and capture impromptu interviews with them. She also collects scripts, broadcast stories and other relevant data. From such multimodal data (Flewitt et al., 2009; Jewitt et al., 2016; Sissons, 2016), one gains

a dynamic constellation of resources, where meanings are produced through the interrelationships between and within the data sets, permitting the researcher literally and metaphorically to 'zoom in' on fine-grained detail and to pan out to gain a broader, socially and culturally situated perspective (Flewitt et al., 2009, p. 44). 
The film data was gathered on November 26, 2016 and transcribed. In terms of analyses, there were two main tools: Textual analysis, which helps us to describe and interpret how people make sense of the world (McKee, 2003), and which, in this paper, focuses primarily on news texts and how the information in them is re-presented; and intertextuality, the practice of reusing and reshaping snatches of other texts (Fairclough, 1992), seen here primarily in the reporter's reshaping of speeches, music and interviews in her news stories.

Overlaid is an interpretative lens reflecting the situated knowledge (Haraway, 1991) and selfreflexivity (Creswell, 2013) of the author, a culturally connected, bilingual Māori woman who is an experienced professional journalist in both mainstream and Māori settings.

\section{Balancing cultural considerations and reporting} Shannon Haunui-Thompson, of the Ngāpuhi iwi, is a senior reporter for RNZ National. At 10am on a hot, windy Saturday morning, she is standing outside the gates of Takitimu marae in rural Te Wairoa, on the east coast of the North Island. The event she is to report is the signing of a Deed of Settlement, an agreement about reparation between the Crown and Te Tira Whakaemi o Te Wairoa, which represents seven clusters of iwi and hapū (subtribes) that together number 34,000 people. 


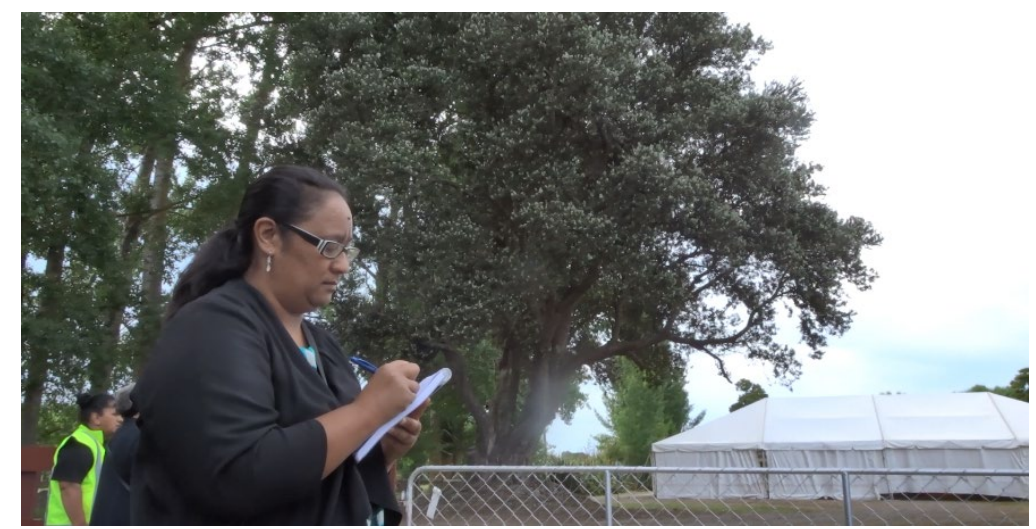

Figure 1: Reporter Shannon Haunui-Thompson waits at the gate at Takitimu marae. All photos and stories in this paper are reproduced with permission.

Today, there are two main activities: A 10am pōwhiri (welcome) ${ }^{2}$ for the tribes that have come to support the local people and, around noon, a second and more elaborate pōwhiri to welcome the Government party with whom the settlement documents will be signed.

A pōwhiri is a marae ceremony in which formal rituals of encounter are undertaken, and a doublepōwhiri arrangement is not uncommon for large formal events. Pōwhiri encapsulate a highly tapu (sacred) set of processes that have persisted, unchanged, for hundreds of years. In the precontact past, these processes discerned the intent of the visitors and provided a space for controlled discussion.

A pōwhiri summons the dead, which imposes on all the state of tapu, or restrictions on what people can

2 For more detail on pōwhiri processes, see Mead, 2003;

Tauroa \& Tauroa, 2009. 
do. Rituals conclude in a state of noa, which Mead (2003) describes as a return to "a state of balance" (p. 95) that allows participants to interact normally. Much Māori news happens within pōwhiri, as they are often called for newsworthy reasons.

Despite the heat of the day, Haunui-Thompson is wearing a long black skirt and a black top that covers her arms. Post-contact, Māori adopted the Victorian custom of wearing black to show respect for the dead (King, 2003), and it remains part of ritual where the dead are summoned. Although the main reason for Haunui-Thompson's presence is the settlement ceremony after the second pōwhiri later in the day, she has a personal, cultural reason for being at the first pōwhiri.

People who have not yet been formally welcomed to a particular marae are called waewae tapu (feet set apart) and this places tapu or restrictions on them (Mead, 2003; Salmond, 2004). Haunui-Thompson is waewae tapu at Takitimu; she has never been formally welcomed on, and she wants to observe the formalities for her own spiritual comfort. The best way to do so, she says, is to attend the first pōwhiri of the day to address her waewae tapu status.

Reporters who are not waewae tapu can simply walk on and sit with the locals. Although HaunuiThompson once went to the back of this marae with a local friend to pick up equipment for a function elsewhere, that quick and informal visit, she says, did not remove her need to follow protocol: "I still want to go through the formal process; that's why I'm here early." She is, she says, always very conscious of her status when on marae.

As she waits, it's clear that most of those assembling are from the Kingitanga, evidenced by the women wearing light blue scarves, a sign of service to the 
current king of the movement, Tuheitia Paki. The Kingitanga, or King Movement, is a pan-tribal movement established in the 1850 s to establish a role similar in status to that of the British monarch to combat the alienation of Māori land. The Kìngitanga remains a powerful spiritual and cultural force among its member tribes (Brooking, 2018).

As she gazes at the crowd gathering at the gates, Haunui-Thompson sees Rahui Papa, a senior Kingitanga figure whom she knows, and goes to greet him with a cheek-kiss and hug. Small groups or individuals at pōwhiri will generally ask permission to accompany the primary group of guests; Haunui-Thompson asks Papa if she can join the Kingitanga group, saying, "Is it alright if we jump on the back?" He replies with a genial, "Yeah, yeah, sweet." The party then stands closely together at the gate to signal readiness.

\section{Entering the marae for the first powhiri ${ }^{3}$}

The first voice heard between guests and hosts at a powwhiri is that of a woman, and her karanga (call) is sacred. ${ }^{4}$ It is

the first expression of welcome ... the karanga provides a safe word pathway, along which the manuhiri [guests] may pass without fear ... the karanga provides the medium by which the living and the dead of the manuhiri may cross the

3 The livestream of the event is on Facebook:

https://www.facebook.com/TatauTatauoTeWairoa/videos/65 $0263771801275 /$

${ }^{4}$ For more detail on the art of karanga, see the Māori

Television series Karanga: The first voice (Reeves \& Mathieson, 2015). 
physical space to unite with the living and dead of the tangata whenua (Tauroa \& Tauroa, 2009, p. $50)$.

The words in karanga vary, but they generally acknowledge the visitors, the reason for the meeting and the dead. On this day, there are multiple kaikaranga on each side, which is not unusual for an important event. Haunui-Thompson walks forward in the middle of the group looking ahead. The tikanga is to remain in a body, remain silent and avoid gazing around (Tauroa \& Tauroa, 2009); it is important to be in the moment. After the kaikaranga of both sides acknowledge the dead, there is a pause while the visitors stand still, eyes down, reflecting on those lost. The host karanga restarts, and manuwhiri are directed to seats facing the hosts. Men sit in the front row, and women behind, a reflection of the traditional imperative to protect women from any malevolence from the other side. Generally, once seated, guests stay put until the end of the ceremony.

On this day, hosts and guests are sitting outside the whare nui under large open-sided tents. HaunuiThompson sits several rows behind the main group. Although her reasons for being at this first pōwhiri are personal, there will still be something worth sending to the newsroom, so she needs to see clearly and have enough room to discreetly take photos while sitting. "During the pōwhiri process I am still considered waewae tapu," she says. "So I try to be discreet and blend in, try not to get in anyone else's way." 


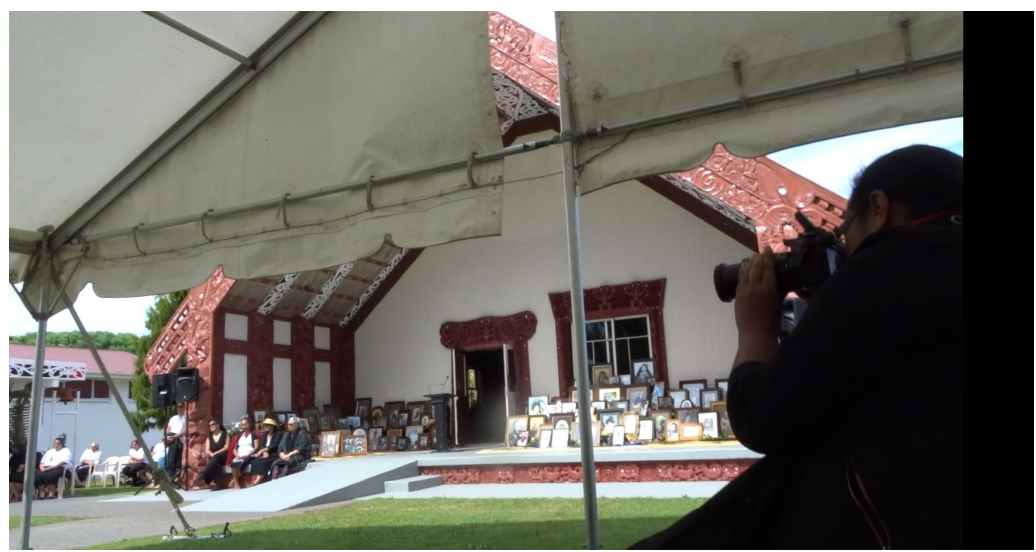

Figure 2: Reporter Shannon Haunui-Thompson takes photographs discreetly from her seat.

\section{Whaikōrero: Debate and discussion}

Whaikōrero is public oratory in the Māori language and draws on tribal history, spirituality, figures of speech and whakapapa (genealogy) (Rewi, 2010). In pōwhiri, once all are seated, men deliver speeches on the business at hand, each speech finished with a waiata (song) by the speaker and his supporters. Haunui-Thompson takes notes of what the speakers say about the settlement to be signed: "The whaikōrero are really important," she whispers. "Sometimes you can pick up good lines ... some history." The speeches also tell her who the leaders are and give her some ideas about who to interview later. While seated, Haunui-Thompson takes the occasional picture with her phone and posts them straight to an RNZ Twitter account (Fig. 3). 
Te Manu Korihi RNZ @TeManuKorihi · 25 Nov 2016

Ngăti Kahungūnu ki Wairoa welcomes Waikato tainui to Takitimu Marae for Deed of Settlement signing with Crown. \#RNZ

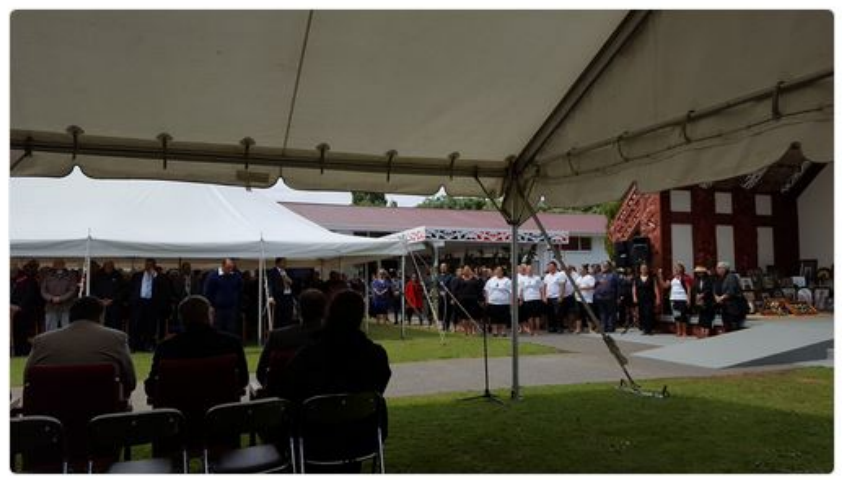

Figure 3: From a back row, the reporter was able to discreetly take pictures.

Haunui-Thompson doesn't record audio from this first pōwhiri as it isn't the focus of her reporting for the day, but does decide that it is worthwhile sending a "reader" back to RNZ - a story for a news announcer to deliver. She taps the script into an email in her phone, and, at 10.30am, still in her seat, sends it:

A delegation from Waikato Tainui representing the Kiingitanga have been welcomed on to Takitimu Marae in Wairoa. The Kiingitanga delegation came to support Ngāti Kahungunu hapū who are signing its Treaty claim Deed of Settlement with the Crown later today. Hundreds of people have arrived at Takitimu Marae for the signing. A formal welcome will be given to Crown representative Chris Finlayson who will also give an apology to Ngāti Kahungunu ki Wairoa. 
Haunui-Thompson pays particular attention when Rahui Papa, the senior figure she had greeted earlier, stands to speak; he is a renowned orator and she knows he will have something pertinent to say. Papa lists the numerous historical links between the Kingitanga and the whare nui (meeting house) standing before him, which is, like the marae complex, called Takitimu. As is common in oratory, he traces the links between hosts and guests, reminding all present that the fourth Māori monarch, Korokī, had opened the building in 1938. Papa also tells his hosts that settlement with the Crown is not an end; it is a beginning, and he warns the iwi to hold the Crown to its promises. HaunuiThompson notes both points and tweets as below.

\section{Te Manu Korihi RNZ @TeManuKorihi·25 Nov 2016}

Waikato-Tainui arrive at Takitimu Marae to support Ngāti Kahungūnu ki Wairoa sign their Deed of Settlement with the Crown. \#RNZ

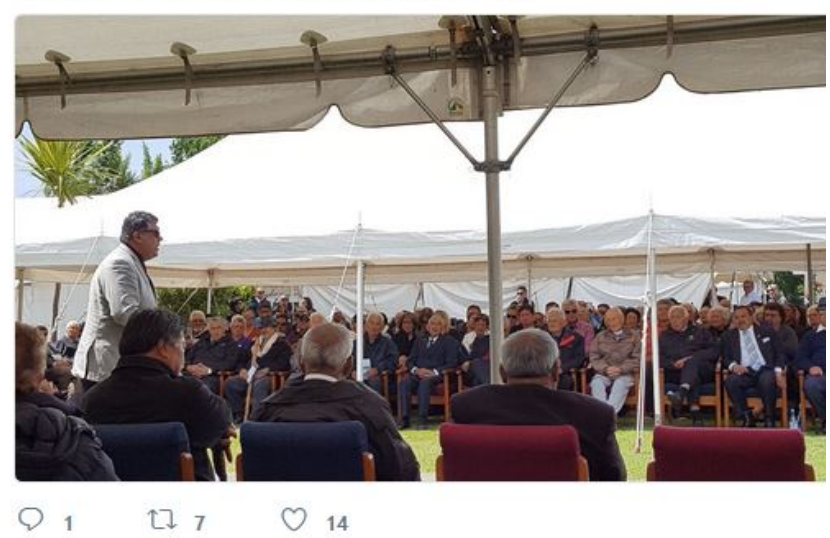

Figure 4: A post sent by the reporter to a RNZ Twitter account. Kiingitanga speaker Rahui Papa addresses the pōwhiri. 
Papa ends his oratory in customary style by leading his supporters in singing a Waikato mōteatea (traditional lament), and then steps forward and places an envelope on the ground containing a koha (donation of money). A leader from the other side collects the envelope, makes some final remarks and indicates that the guests should cross the marae àtea, the open space between visitors and guests, for the hongi and harirū.

\section{Hongi and harirū}

The hongi, in which participants press the tips of the nose, mingles the breath of both in a symbolic display of unity. It recalls the legend of the first woman, Hineahuone: the god Tâne fashioned her from red clay and then breathed life into her nostrils (Duncan \& Rewi, 2018). As they hongi, people generally shake hands, called harirū in te reo, ${ }^{5}$ and give a short greeting such as "tēnā koe", which we can translate as "I see/acknowledge you". Foreheads might touch; some tribes press noses twice, and some press on the side of the nose.

Physical contact removes the tapu that previously existed between hosts and guests and the latter can move freely (Salmond, 2004; Tauroa \& Tauroa, 2009). Although she has to do harirū as a guest in order pass from tapu to noa, Haunui-Thompson also takes the opportunity to identify herself quickly to several people and asks to speak to them later. They all agree.

Those who have completed hongi and harirū head to the whare kai for morning tea; cooked food also

\footnotetext{
${ }^{5}$ Harirū means handshake and is a transliteration of "how do you do?" (Duncan \& Rewi, 2018).
} 
serves to remove tapu (Mead, 2003). HaunuiThompson wants to do a story for the midday bulletin, so, still standing, taps a script into her phone and emails it to her news desk for checking. Once it's cleared, she returns to her car, parked nearby, records the script from the driver's seat and sends it to the office via her laptop. This is the script:

A delegation from Waikato-Tainui have been welcomed on to Takitimu Marae, which was opened by Kiingi Koroki.

They came to support the signing and to offer some advice. During the whaikōrero, Rahui Papa said even though the Crown will deliver an apology today, to make sure it stands by it.

The Treaty Minister, Chris Finlayson, will sign the Deed on behalf of the Crown and deliver an apology. A full pōwhiri will be given to Mr Finlayson when he arrives at the marae later today.

I Wairoa, ko Shannon Haunui-Thompson ahau (Translation: From Wairoa, this is Shannon Haunui-Thompson).

In making an intertextual reference to Korokī, the fourth Māori monarch (1906-1966), she draws a link between Kahungunu and Waikato-Tainui, reminding Māori listeners of the tribes' longstanding ties; this reference would probably be lost to nonMāori listeners. In reporting Papa's advice to keep the Crown honest, the story alludes to another fact that those interested in Aotearoa New Zealand's history would know: Waikato was among the first tribes to settle its land claim, in 1995 (Fisher, 2016) and has since been a model for other tribes. 


\section{The second pōwhiri}

As Haunui-Thompson is emailing her story to the news desk, she hears that the Crown party of some 15 people has arrived and is standing at the end of the long driveway leading to the marae. She moves quickly to the side of the driveway, in hand a camera with a telephoto lens. She captures the action as five warriors sprint down the driveway to deliver a ceremonial wero, an honour accorded to distinguished visitors (see figure 5), but takes care not to get between the two parties, as this is now a space under tapu.

The word wero means to 'to cast a spear' and was originally a tactic of the ancestors to help determine the intent of those approaching. Warriors use elaborate and synchronised moves to demonstrate their physical prowess (Duncan \& Rewi, 2018; Tauroa \& Tauroa, 2009). One of them then places on the ground before the visitors a small symbolic item such as a leafed branch, a wreath, or a small wooden taki (dart), while holding eye contact with the leader of the guests. Once that leader accepts the offering, the warriors lead the group to the marae àtea.

In a full wero, there are three separate challenges by three different warriors, rather than the usual one, and this is the case today. ${ }^{6}$ After photographing the activity, Haunui-Thompson walks back onto the marae through a side entrance, where karanga are filling the air. She photographs the stirring haka (posture dance) that erupts. Afterwards, she returns to her car to download and send her pictures,

\footnotetext{
${ }^{6}$ For details on the role of each warrior, see Tauroa and Tauroa, 2009.
} 
keeping an ear on the master of ceremonies as he opens proceedings.

t] Te Manu Korihi RNZ Retweeted

Shannon Haunui @SHaunui ·25 Nov 2016

Treaty Minister, Chris Finlayson arrives at Takitimu Marae for Deed of Settlement signing with Ngåti Kahungũnu ki Wairoa \#RNZ

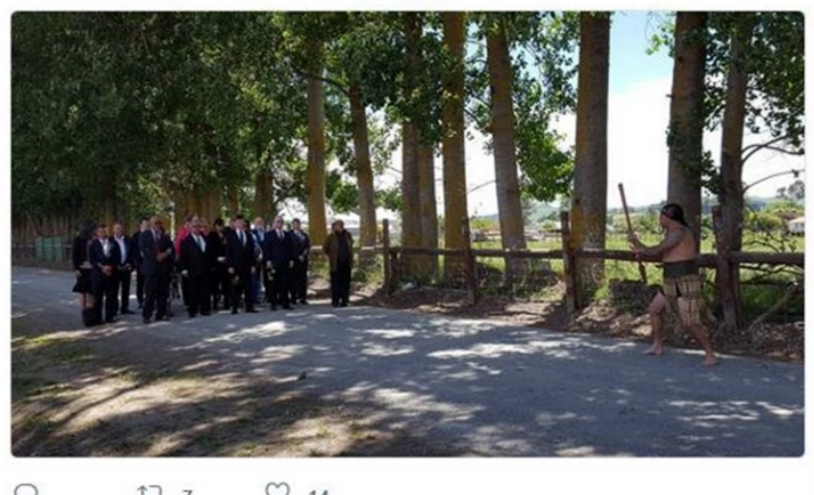

Figure 5: Shannon Haunui-Thompson's picture for Twitter of the Crown party, just after its leaders have picked up the taki. The kaiwero (challenger), on the right, prepares to lead the guests to the marae.

Pōwhiri are usually a wholly reo-Māori affair. This pōwhiri has been modified, as it needs to incorporate several speeches in English and the signing of paper deeds on a long table set up before the whare nui. Haunui-Thompson records the speakers, who include the tribe's chief negotiator; the country's Governor-General, who supervised the truth and reconciliation report that formed part of 
the pathway to settlement, ${ }^{7}$ and the Minister for Treaty of Waitangi Negotiations, Chris Finlayson.

For Haunui-Thompson, the most important elements in a settlement story are what the iwi will get in redress, what it hopes to achieve, "and how they feel on the actual day - usually they're quite emotional". Recording good "atmos", or atmospheric audio, is also important to Haunui-Thompson and she likes using the waiata that conclude speeches. She has been hoping to hear a well-known song from the region, Tütira mai ngā iwi, and when it begins is quick to record it:

Tūtira mai ngā iwi

Tātau tātau e

Tūtira mai ngā iwi

Tātau tātau e

Whāia te māramatanga

me te aroha

E ngā iwi! Kia tapatahi

Kia kotahi rā

Tātau tātau e

Tātau tātau e
Come together as one

All of us, all of us

Come together as one

All of us, all of us

Seek understanding and compassion

People! Be united, think of ourselves as one people

Stand as one

All of us, all of us

All of us, all of us

This song is also very well-known to born-andraised New Zealanders as it has been taught in primary schools since the 1960s (Gardiner, 2017). Later, Haunui-Thompson says that as the tribe's post-settlement body is named Tâtau Tātau after the

\footnotetext{
7 This report was modelled on the Truth and Reconciliation Commissions that were established under President Nelson Mandela in post-apartheid South Africa (Te Tira Whakaemi o Te Wairoa, 2014).
} 
key lines in the song, it's nice symbolism for her to use that music. 8

Later, as the settlement documents are signed on a long table, she notes who is representing the iwi. As an elderly woman in a traditional cloak steps away from the table, Haunui-Thompson approaches, and, addressing her respectfully as whaea (aunty), asks if she can interview her. The woman, Pauline Tangiora, is articulate and forthright, and tells Haunui-Thompson that she and her husband were among the seven people who had laid the original claim for redress three decades before. That very day, the kuia (elderly woman) says, her eyes filling with tears, is the 30th anniversary of his death. Haunui-Thompson makes a comforting noise, puts a consoling hand on the kuia's upper back and keeps it there until the interview ends three minutes later. Finishing, she says, "Enjoy the moment, whaea. You deserve it ... thank you for your time." She takes a couple of pictures of the kuia sitting with a relative.

Guests and hosts are mingling on the marae ātea. Haunui-Thompson interviews the Treaty Minister, an interview she had arranged ahead of time with his staff; the Governor General, and the iwi's chief negotiator.

8 The song was written by Canon Wiremu Te Tau Huata in the late 1950s while he was driving with his children past Lake Tūtira, near Te Wairoa. The phrase Tūtira mai ngā iwi, tātau, tātau is now regarded as a kīwaha or figure of speech by Ngāti Kahungunu (Gardiner, 2017; Tomoana, 2015). 


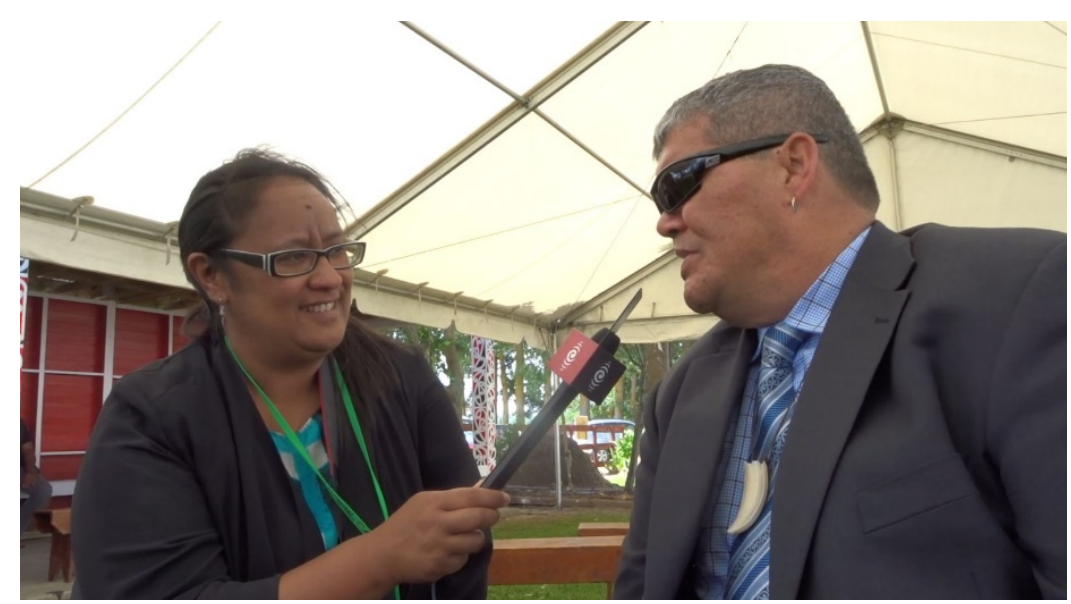

Figure 6: Shannon Haunui-Thompson interviews iwi chief negotiator John Whaanga.

\section{Filing for radio and website}

As the formalities close and guests move to the whare kai for the hākari (feast), Haunui-Thompson returns to the car to send back "news cuts" for the $5 \mathrm{pm}$ bulletin - in this case, a story wrapping up the day. Her $1 \mathrm{~m} \mathrm{25s}$ report is the lead on the $5 \mathrm{pm}$ news: (Presenter): Wairoa iwi and hapū signed a Deed of Settlement with the Government today. Hundreds gathered at Tākitimu Marae to celebrate the signing and to hear the Crown's apology. Te Manu Korihi ${ }^{9}$ reporter Shannon Haunui-Thompson was there. (Reporter) For more than 30 years, the iwi and hapu of Wairoa have been working on their Treaty settlement with the Crown. It's the fifth largest Treaty of Waitangi settlement to date and includes financial redress of 100 million dollars. Pauline

\footnotetext{
9 Te Manu Korihi (the singing bird) was the name given to Māori news at RNZ National at the time.
} 
Tangiora was one of the first people to initial the settlement, more than 30 years ago.

(Audio, Pauline Tangiora) "It's a great relief to know the job is finished for our rohe and that we now pass it on to the next stage and that we hopefully, that they will settle for the benefit of the beneficiaries in peace and harmony."

(Reporter) The Treaty Minister, Chris Finlayson, delivered an apology to Ngāti Kahungunu ki Wairoa on behalf of the Crown and said what the Crown did in Wairoa led to economic decline and deprivation for the region.

(Audio, Chris Finlayson) "The degree of land loss, the complex historical interactions with the Crown and really redressing the economic deprivation of this Wairoa region."

(Reporter) The newly-established post-settlement governance entity has two years to formulate a business and social plan for the settlement money. Kei Wairoa i Takitimu Marae, ko Shannon HaunuiThompson ahau [I'm Shannon Haunui-Thompson at Takitimu Marae, Wairoa].

An abridged version of this is the lead story at $6 \mathrm{pm}$. Haunui-Thompson is finally able to have a break and goes to the whare kai (dining hall) to eat. Later, back at her accommodation, she writes her news feature for the web (below), which is uploaded at $9 \mathrm{pm}$ that night. 10

\footnotetext{
10 The story is at https://www.radionz.co.nz/news/te-manukorihi/318982/govt-sorry-for-taking-iwi\%27s-land.
} 
TE AO MĀORI / POLITICS

\section{Wairoa iwi Treaty settlement marked by Govt}

\section{apology}

The Government has apologised for stealing land from iwi as it signed a Treaty settlement with Ngati Kahungūnu ki Te Wairoa today.

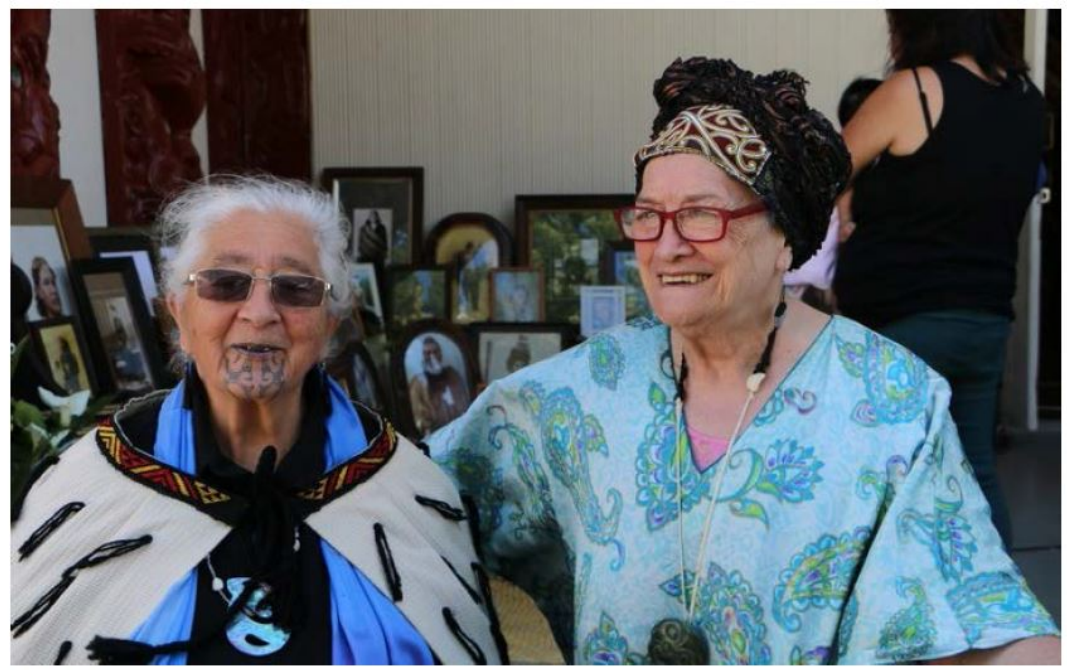

Pauline Tangiora and Rose Pere. Photo: RNZ/ Shannon Haunui-Thompson 
Hundreds gathered at Takitimu Marae to celebrate the signing and hear the Crown's apology.

The iwi and hapu of Wairoa have worked on their treaty settlement for more than 30 years. It is the fifth largest Treaty of Waitangi settlement to date and includes a $\$ 100$ million payment.

Treaty Negotiations Minister Chris Finlayson spoke about the Crown's role in taking, by force, land from Ngati Kahungūnu ki Te Wairoa and apologised for the Crown's role in the iwi's loss of land.

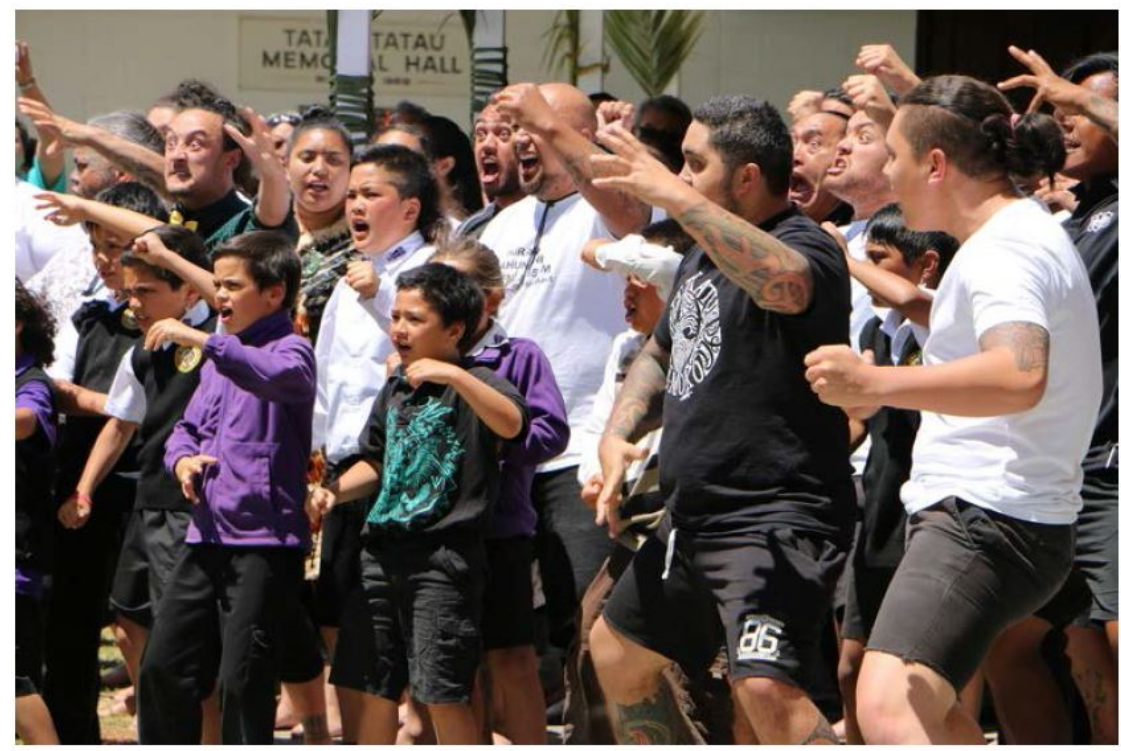

Iwi members young and old lay down the challenge with a haka. Photo: RNZ / Shannon Haunui-Thompson 
Mr Finlayson said he regretted the destructive and demoralising effect the confiscation had on the Ngati kahungunu ki Te Wairoa hapū.

"The Crown can never fully compensate for the wrongs of the past, but this settlement provides the people of Te Wairoa with the foundation for a stronger cultural and economic future," he said.

Mr Finlayson said intense military campaigns against Te Wairoa led to socio-economic deprivation, which still existed.

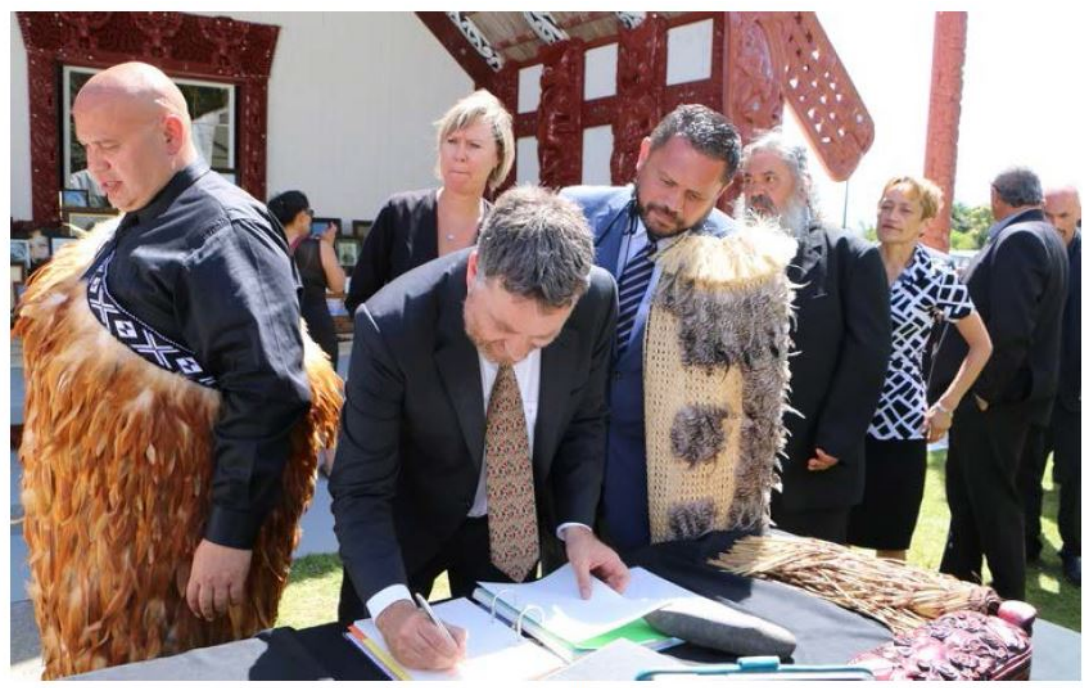

The iwi and hapū of Te Wairoa have worked on their treaty settlement for more than 30 years. Photo: RNZ / Shannon Haunui-Thompson

Pauline Tangiora was one of the first people to start the settlement more than 30 years ago. "It's a great relief that the job has finished for our rohe, we now pass it on to the next stage and hopefully they'll settle for the benefit of the beneficiaries in peace and harmony."

The newly-established Post-Settlement Governance Entity, Tatau Tatau o Te Wairoa Trust, has two years to formulate a business and social plan for the settlement money. 


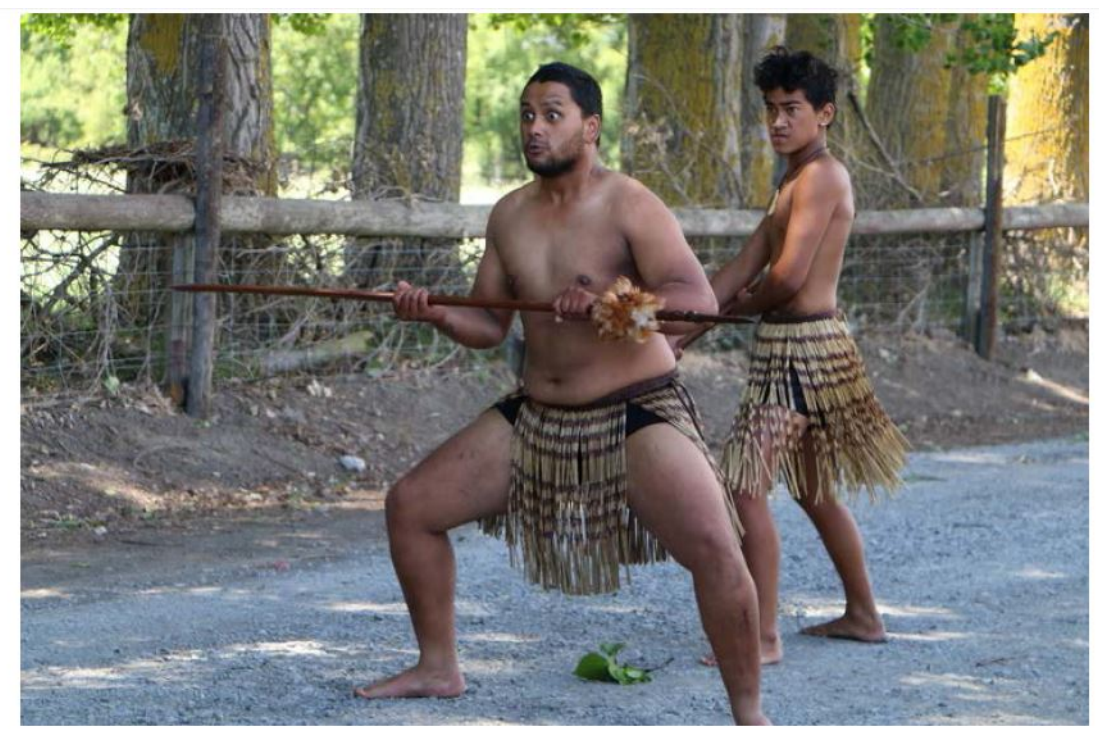

The full pōwhiri welcomes Mr Finlayson onto the marae grounds. Photo: RNZ / Shannon Haunui-Thompson

During the whaikōrero today, Kiingitanga advisor Rahui Papa said the Crown needed to stand by its apology.

It was to redress a grievance from a Crown attack on the iwi on Christmas Day, 1865, which resulted in loss of life and property.

The iwi and hapū of Te Rohe o Te Wairoa includes seven iwi and hapū covering northern Hawke's Bay, southern Gisborne, the township of Wairoa, Lake Waikaremoana and the Mahia peninsula.

\section{The Monday morning wrap}

The next day, a Sunday, Haunui-Thompson is still in Wairoa and spends several hours preparing a 3 min 39 sec feature for Monday morning's flagship news show, Morning Report. It is transcribed below and the report itself is on the landing page for this paper. 


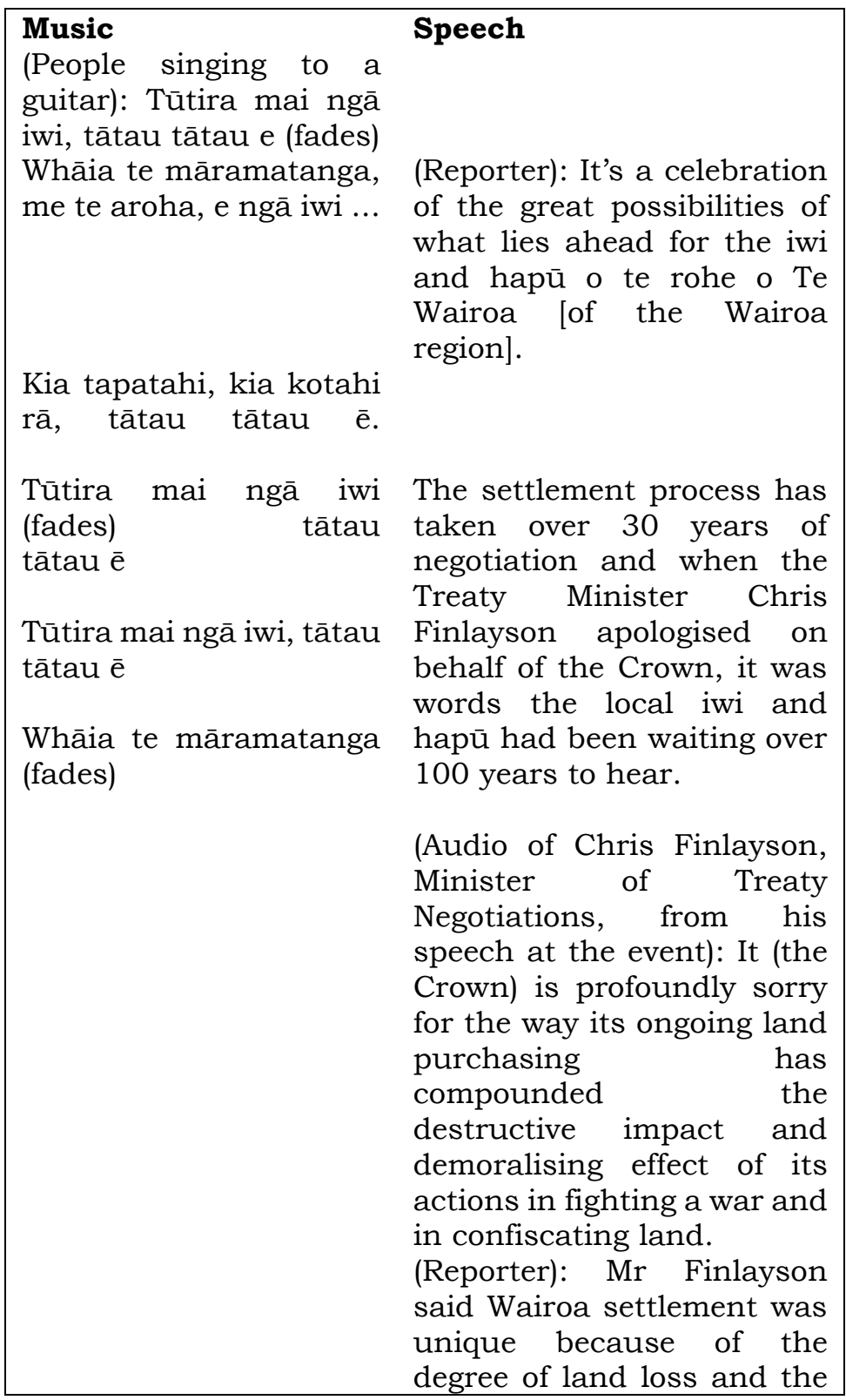




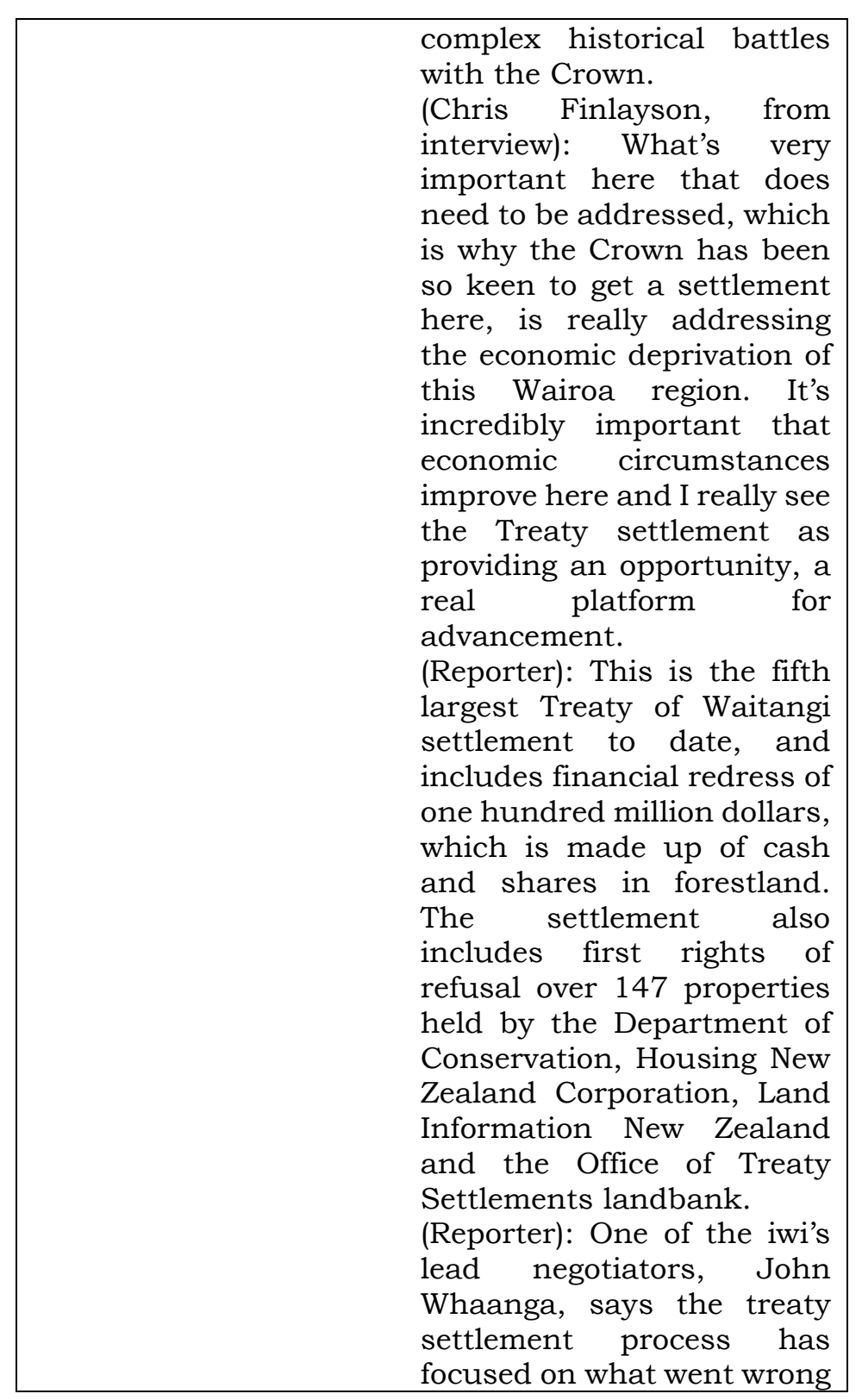




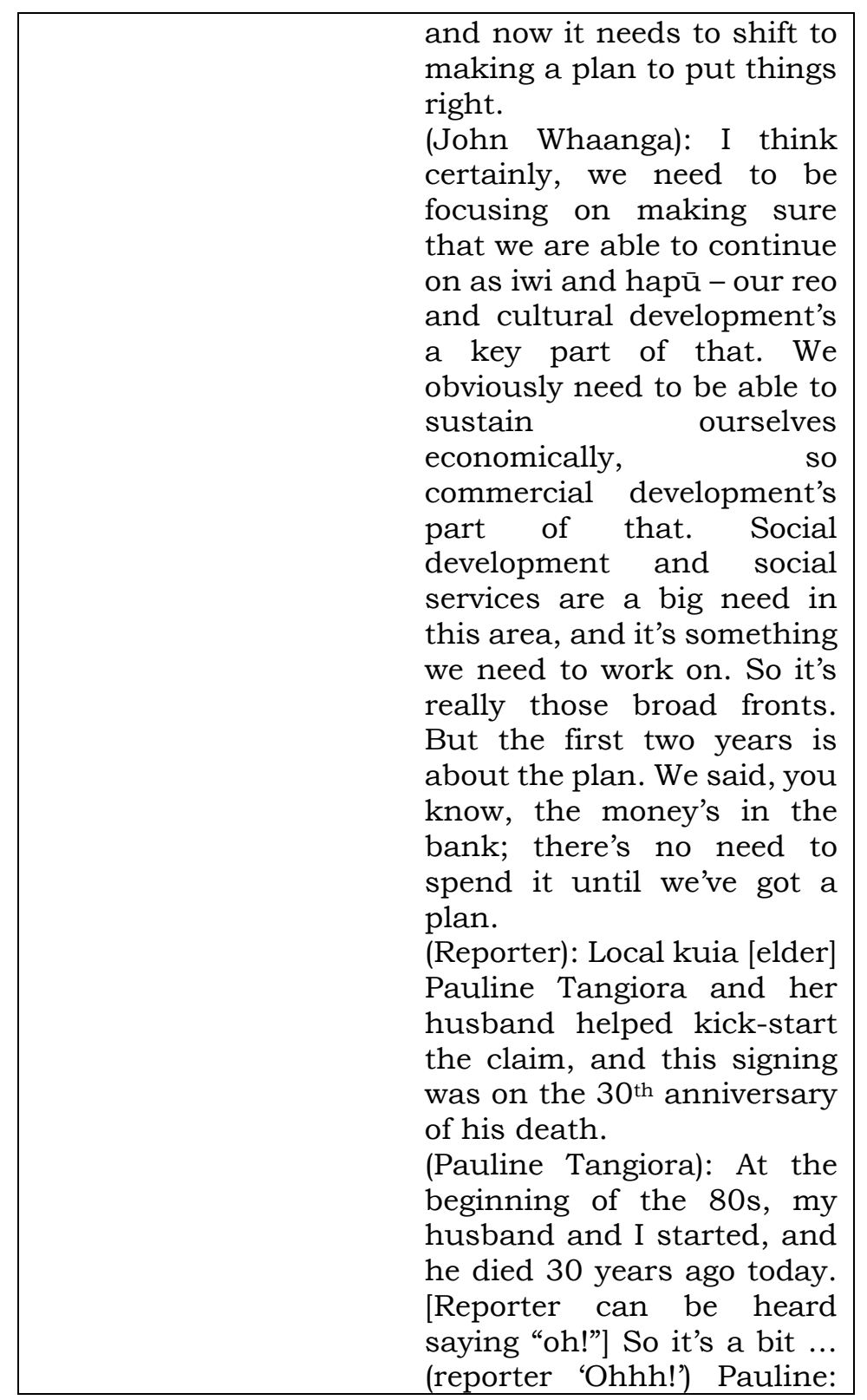




\begin{tabular}{|c|c|}
\hline $\begin{array}{l}\text { Singing fades in: Tātau ē } \\
\text { Tātau tātau è }\end{array}$ & $\begin{array}{l}\text { So it's a bit ... (unable to } \\
\text { finish sentence; reporter } \\
\text { can be heard saying "ohhh' } \\
\text { in a comforting way). } \\
\text { (Reporter) Ms Tangiora says } \\
\text { all the hard work put into } \\
\text { the settlement has been for } \\
\text { the beneficiaries. "It is for } \\
\text { the } 36,000 \text { beneficiaries and } \\
\text { that is what I believe we } \\
\text { have done through these } \\
\text { years of the settlement, is } \\
\text { remembering that we were } \\
\text { there for } 36,000-\text { plus } \\
\text { beneficiaries of our rohe." } \\
\text { (Reporter): A newly formed } \\
\text { entity, Tātau Tătau o Te } \\
\text { Wairoa Trust, has now two } \\
\text { years to formulate a plan on } \\
\text { how to use the money and } \\
\text { create an economic and } \\
\text { social plan for the iwi's } \\
\text { future. Mō Te Hōtaka o te } \\
\text { Ata nei, ko Shannon } \\
\text { Haunui-Thompson ahau } \\
\text { [For Morning Report, this is } \\
\text { Shannon Haunui- } \\
\text { Thompson]. }\end{array}$ \\
\hline
\end{tabular}

\section{Discussion}

News values through a Māori lens

Over the past 40 years, much research has explored the factors that determine the prominence and resources given to a news story, starting with the foundational work of Galtung \& Ruge (1965), with important contributions since by researchers such 
as Bell (1991), Harcup and O’Neill (2016, 2001), Masterton (1990), and McGregor (2002). This paper assumes that readers have some understanding of news media values, and they will not be explored here.

Māori journalism uses the news values of the AngloAmerican journalism journalistic tradition, but views them through a Māori cultural, political and social lens rather than that of mainstream, Pākehādominated society (Middleton, 2020a). As a reporter, Haunui-Thompson is writing for a national audience, but brings her own sensibility as Māori to this story.

Standard news values remain present in journalism that centres a Māori perspective, such as values in the news text, which include clarity and brevity; value in the news process, such as stories that can meet deadlines; and, mostly importantly, values in news actors and events. These include values such as proximity to the audience, negativity, unambiguity, threshold (the size of an event), frequency (how neatly it fits into the production cycle), unexpectedness, reference to elite people and/or nations, drama, emotion, striking images and conflict (Galtung \& Ruge, 1965; Harcup \& O’Neill, 2016; McGregor, 2002).

The most prominent news value in operation in her story is good news, defined as a story with "particularly positive overtones" (Harcup \& O'Neill, 2016 , p. 13). After three decades of work by the tribe to prove its claim, the wrongs done in the $19^{\text {th }}$ century were acknowledged and compensated, and the Government and tribe came together in reconciliation. Another is consequence, or " $\mathrm{a}$ measure of how many people will be affected by a story's content" (Masterton, 1998, p. 92). Here, the 
$\$ 100$ million settlement promised to have a significant impact on the economic, cultural and social wellbeing of a relatively poor and isolated tribe of some 34,000 people.

Relevance, or "stories about groups or nations perceived to be influential with, or culturally or historically familiar to, the audience" (Harcup \& O'Neill, 2016, p.13) is another news value in evidence here. The Māori world is small and interconnected, and many people who were not directly involved with the settlement itself would have blood or marriage links to the tribe and would benefit from its post-settlement activities. Almost all tribes were affected by war and land loss in the 1800 s, and many suffered disastrous dispossession (Anderson et al., 2014). While many tribes have settled with the Crown, numerous claims remain unresolved and iwi are therefore intensely interested in other tribes' progress.

Recency. According to Bell (1991), "the best news is something which has only just happened" (p. 157), and in the digital age, consumers expect that news is reported immediately and through various platforms. From the beginning of the formal activity, the reporter discreetly took photographs from a rear seat, tweeting two in the first hour (see figures 3-5). Once the pōwhiri was over, she returned to her car to send voice reports and audio.

The power elite, or "stories concerning powerful individuals, organisations, institutions or corporations" (Harcup \& O’Neill, 2001, p. 14) is another value present. Here, the elite people are Government ministers and the iwi leaders to whom they apologised. However, the pictures show which group was most important in this paradigm: the images feature Māori leaders rather than Crown 
officials. From a (Māori) news selection point of view, Crown officials are present at all settlement ceremonies; there is nothing visually new in that. However, the ceremonial activity of the local people at this time and place is unique.

This story is also an example of follow-up of a subject already in the news (Harcup \& O'Neill, 2001). The iwi had spent 30 years working towards settlement, and in the final years, RNZ National had done several reports. In addition, the story offered unambiguity (Galtung \& Ruge, 1965; Bell, 1991), defined as "the more clear-cut a story, the more it is favoured ... the facts are clear, the sources impeccable" (Bell, 1991, p. 157). This story was straightforward and typical of settlement stories. The Crown came to the iwi's land and was welcomed with ceremony, admitted it stole land from iwi, publicly apologised to the iwi and paid compensation. The story also had consonance (Galtung \& Ruge, 1965), or predictability as Bell (1991) terms it. Treaty settlements have been underway for 30 years and newsrooms are informed of new developments well in advance.

This story also bore a critical news value for the digital age - visualness (McGregor, 1992), which, "as a primary, elite news value acknowledges the special power of presenting news through pictures" (ibid., p.3). Appealing on-the-scene pictures increase the likelihood a story will get resources (McGregor, 2002), and this report includes four. The pictures also increase the story's shareability, the likelihood they would "generate sharing and comments via Facebook, Twitter and other forms of social media" (Harcup \& O'Neill, 2016, p. 13). On RNZ National's Facebook page, the story got 98 likes or loves, with no negative reactions. There were 13 
comments, mostly the names of those who had been tagged.

\section{The use of te reo Māori in English-language reporting}

Haunui-Thompson's stories use Māori words and ideas that are part of New Zealand English and widely understood (Bellett, 1995; Macalister, 2006).The increasing normalisation of Māori language and culture (Benton, 2015; Blundell, 2018; Crewsden, 2017) is underlined by the fact that certain issues and concepts from te reo Māori are no longer glossed or described in Englishlanguage media (de Bres, 2006; Kennedy \& Yamazaki, 2000; Peacock, 2017; Roy, 2017).

For example, in Haunui-Thompson's internet story, there are seven Māori words: iwi (tribe), hapū (subtribe), haka (posture dance), rohe (region), pōwhiri (welcome), marae (meeting place) and whaikōrero (oratory). These are among the most common Māori words and phrases in New Zealand English (Bauer, 1995; Bellett, 1995; Deverson, 1991; Kennedy, 2001; Macalister, 2006, 2008). Haunui-Thompson does not translate them because "they are commonly used words, not just by Māori, but by Pākehā”.

Haunui-Thompson consciously uses macrons, or tohutō, in Māori words - the dash above a vowel that indicates it is pronounced twice the length of one without, giving a word a different meaning. For example, ata is a noun that means morning, but āta is a modifier that stands before verbs to indicate care, deliberation or thoroughness. In the early to mid-19th century, as written Māori developed, all 
Māori were native speakers, making pronunciation reminders unnecessary.

However, by the late 20th century, with the language in decline, it was necessary to settle on a way to help speakers and learners maintain correct pronunciation. Te Taura Whiri, the Māori Language Commission, in 2009 produced a guide to orthography ${ }^{11}$ that is the standard for people using te reo Māori in both English and Māori-language contexts. Haunui-Thompson describes it as her "most reliable reference".

However, one word in her internet story was spelled with double vowels, an alternative to the macron, and that's Kiingitanga, the King Movement. For historical reasons, the Kiingitanga and the administrative arm of Waikato-Tainui, which are closely related, have not adopted the macron ('Taaonga Tuku Iho', 2018), and appear to be the only Māori organisations to eschew it. In following suit, the reporter is demonstrating respect for the tribe's mana motuhake or independence: "It's an acknowledgement of them and how they have chosen to spell that word," she said.

The reporter looked at the event through a Māori lens, but wrote her stories in a way that aimed to be inclusive of all listeners, given RNZ National's remit. Therefore, the story 'Iwi gets $\$ 100 m$ Treaty settlement' focused on what settlements meant for Māori rather than the dominant culture or the Government, but made explicit the history behind the settlement by briefly describing the 19th-century attack by Crown soldiers that dispossessed the iwi. This is necessary as many non-Māori New Zealanders know little of local history or the Māori

11 The guide is at https://www.reomaori.co.nz/orthography 
perspective on that history (Sheehan \& Ball, 2020), and adult understanding of Tiriti-related processes may be poor.

The story upheld the place of te reo Māori an official language by not translating Māori words in common use, as well as adopting the particular spelling of a Māori political movement to reflect that movement's self-determination.

RNZ National is, like most news media in the digital age, a multi-platform news provider, and this is reflected in the reporter's substantial output: images for Twitter, stories both long and short form for broadcast, and a news feature for the website.

In terms of images, Māori faces are prioritised; the first picture honours the elders who had been involved for more than 30 years in negotiating the settlement, underlining not just their status, but the fact that many of them had spent their entire adult lives seeking redress. The tribal elite were shown signing documents rather than Government ministers.

Two photos show cultural activities that have great meaning in formal Māori arenas - the wero and an energetic action song.

This reporter's work takes place in, and responds to, a country where Māori are increasingly asserting their rights as Tiriti partners, and non-Māori are increasingly responding to the call of biculturalism, which we can define as "both cultures existing side by side in New Zealand, each enriching and informing the other" (Waitangi Tribunal, 1999, p. xi). In documenting a Māori journalist at work, this paper, perhaps, begins a resource collection that will help build bicultural understanding and practice in our news media. 


\section{Conclusion}

The research question was this: How does a Māori reporter working for a mainstream news service centre the indigenous perspective on an event while clearly communicating to a national audience? In terms of her newswork, she focused on the Māori viewpoint but ensured that there was enough contextual information for those whose knowledge of Tiriti processes might be limited. In the same vein, she asserted her identity and the increasingly positive social environment around te reo Māori by using small amounts of the language, but employed words that are well-known to most New Zealanders. Importantly, the reporter was able to balance her own need to respect and perform tikanga in accordance with her cultural beliefs and the need to get the job of journalism done. Acutely aware of cultural norms, she organised her day in order to pass early through the necessary protocols as a first-time visitor to the marae, after which she was able to move freely on the site and focus on her newswork.

\section{Acknowledgements}

Many thanks to Shannon Haunui-Thompson for her assistance and to Associate Professor Helen Sissons for her suggestions to improve this article. This research has AUT ethics approval (16/04). 


\section{References}

Adds, P., Bennett, M., Hall, M., Kernot, B., Russell, M., \& Walker, T. (2005). The portrayal of Māori and te ao Māori in broadcasting: The foreshore and seabed issue. Broadcasting Standards Authority. https://bsa.govt.nz/publications/research/832001-2005/5785-the-portrayal-of-maori-and-te-aomaori-in-broadcasting-the-foreshore-and-seabedissue

Anderson, A., Binney, J., \& Harris, A. (2014). Tangata whenua: An illustrated history. Bridget Williams Books.

Bauer, W. (1995). Languages in contact II: The use of Maori words in English. The Journal of New Zealand Studies, https://ojs.victoria.ac.nz/jnzs/article/view/474

$5(2)$. Bell, A. (1991). The language of news media. Blackwell. Bellett, D. (1995). Hakas, hangis, and Kiwis: Māori lexical influence on New Zealand English. Te Reo, 38, 73-103.

Benton, R. (2015). Perfecting the partnership: Revitalising the Māori language in New Zealand education and society 1987-2014. Language, Culture and Curriculum, 28(2), 99-112. https://doi.org/10.1080/07908318.2015.1025001 Blundell, S. (2018, June 30). Tiakina te reo. New Zealand Listener, pp. 27-30.

Brooking, T. (2018) He takaoraora, he whakameto: Struggle and advancing in a stealthy manner, 18811918. In M. P. J. Reilly, G. Leoni, L. Carter, S. Duncan, L. Paterson, M. T. Ratima, \& P. Rewi (Eds.), Te Kōparapara: An introduction to the Māori world, pp. 224-244. Auckland University Press.

Bryman, A. (2012). Social research methods (4th ed.). Oxford University Press. 
crewel, S. (2000). New(s) times: Towards a 'second wave' of news ethnography. Communications: The European Journal of Communication Research, 25(1), 19-41.

https://doi.org/10.1515/comm.2000.25.1.19

Cottle, S. (2007). Ethnography and news production: New(s) developments in the field. Sociology Compass, $1(1)$, 1-16. https://doi.org/10.1111/j.17519020.2007.00002.x

Creswell, J. W. (2013). Qualitative research and design: Choosing among five approaches (3rd ed.). SAGE.

Crewsden, P. (2017, September 1). Why Stuff is introducing macrons for te reo Mãori words. Stuff.co.nz.

https://www.stuff.co.nz/national/96578644/whystuff-is-introducing-macrons-for-te-reo-maoriwords

Davidson, C., \& Tolich, M. (Eds.). (2003). Social science research in New Zealand (2nd ed.). Pearson Education New Zealand.

de Bres, J. (2006). Maori lexical items in the mainstream television news in New Zealand. New Zealand English Journal, 20(17). https://www.wgtn.ac.nz/lals/resources/publicatio ns/nzej-backissues/2006-julia-de-bres.pdf

Deverson, T. (1991). New Zealand English lexis: The Maori dimension. English Today, 7(2), 18-25. https://doi.org/10.1017/S0266078400005496

Duncan, S., \& Rewi, P. (2018). Ritual today: Pōwhiri. In M. P. J. Reilly, G. Leoni, L. Carter, S. Duncan, L. Paterson, M. T. Ratima, \& P. Rewi (Eds.), Te Kōparapara: An introduction to the Mãori world, pp. 121-136. Auckland University Press. 
Fairclough, N. (1992). Discourse and social change. Polity Press, 1992.

Fisher, M. (2016). The politics of history and WaikatoTainui's raupatu Treaty settlement: Live. New Zealand Journal of History, 60(2), 68-89. http://www.nzjh.auckland.ac.nz/docs/2016/NZJ H_50_2_04.pdf

Flewitt, R., Hampel, R., Hauck, M., \& Lancaster, L. (2009). What are multimodal data and transcription? In The Routledge handbook of multimodal analysis (pp. 40-53). Routledge.

Flyvbjerg, B. (2006). Five misunderstandings about case-study research. Qualitative Inquiry, 12(2), 219245. https://doi.org/10.1177/1077800405284363

Galtung, J., \& Ruge, M. H. (1965). The structure of foreign news. Journal of Peace Research, 2(1), 6491. http://www.jstor.org/stable/423011

Gardiner, H. (2017, July 7). Kawe Kōrero sings Tūtira Mai with composer's daughter. Māori Television. https://www.maoritelevision.com/news/national/ kawe-korero-sings-tutira-mai-composers-daughter

Hanusch, F. (2013). Cultural forces in journalism: The impact of cultural values on Māori journalists' professional views. Journalism Studies, 16(2), 191206.

https://doi.org/10.1080/1461670X.2013.859864

Haraway, D. (1991). Simians, cyborgs, and women: The reinvention of nature. Taylor $\&$ Francis.

Harcup, T., \& O'Neill, D. (2001). What is news? Galtung and Ruge revisited. Journalism Studies, 2(2), 261-279.

https://doi.org/10.1080/14616700118449

Harcup, T., \& O’Neill, D. (2016). What is news? News values revisited (again). Journalism Studies, 1-19. https://doi.org/10.1080/1461670X.2016.1150193 
Holmes, J. (2003). Narrative structure: Some contrasts. In C. B. Paulston \& G. R. Tucker (Eds.), Sociolinguistics: The essential readings (1st ed., pp. 114-138). Blackwell.

Irwin, K. (1994). Maori research methods and practices. Sites, 28, 25-43.

Jewitt, C., Bezemer, J. J., \& O’Halloran, K. L. (2016). Introducing multimodality. Routledge.

Kennedy, G. (2001). Lexical borrowing from Maori in New Zealand English. In B. Moore (Ed.), Who's centric now? The present state of post-colonial Englishes. Oxford University Press.

Kennedy, G., \& Yamazaki, S. (2000). The influence of Māori on the New Zealand English lexicon. In Corpora galore: Analyses and techniques in describing English: Papers from the nineteenth International Conference on English Language Research on Computerised Corpora (ICAME 1998) (pp. 33-44). Rodopi.

King, M. (2003). The Penguin history of New Zealand. Penguin Books.

Macalister, J. (2006). The Maori presence in the New Zealand English lexicon, 1850-2000: Evidence from a corpus-based study. English World-Wide, 27(1), 124. https://doi.org/10.1075/eww.27.1.02mac

Macalister, J. (2008). Tracking changes in familiarity with borrowings from te reo Maori. Te Reo, 51, 75.

Markelin, L. (2017). Indigenous voices in the global public sphere: Analysis of approaches to journalism within the WITBN network. Journal of Applied Journalism \& Media Studies, 6(3), 443-461. https://doi.org/10.1386/ajms.6.3.443_1

Masterton, M. (1990). What makes news? An international study of the criteria of newsworthiness [PhD thesis, Flinders University]. 
McGregor, J. (2002, July 10). Restating news values: Contemporary criteria for selecting the news. Australian \& New Zealand Communication Association Conference, Gold Coast, Queensland. http://www.anzca.net/documents/2002-confpapers /382-restating-news-values-contemporarycriteria-for-selecting-the-news-1.html?path $=2002$ conf-papers

McKee, A. (2003). Textual analysis: A beginner's guide. SAGE.

Mead, H. (2003). Tikanga Mãori: Living by Mãori values. Huia.

Middleton, A. (2020a). Kia hiwa rā! The influence of tikanga and the language revitalisation agenda on the practices and perspectives of Māori journalists working in reo-Māori news [PhD thesis, Auckland University of Technology]. https://openrepository.aut.ac.nz/handle/10292/1 $\underline{3286}$

Middleton, A. (2020b). Māori-language and Māoriinterest media. In M. Myllylahti and W. Hope (Eds.), JMAD New Zealand Media Ownership 2020. https://openrepository.aut.ac.nz/handle/10292/1 $\underline{3929}$

Myllylahti, M., \& Treadwell, G. (2020). Trust in news in New Zealand. Auckland University of Technology. https://www.jmadresearch.com/_files/ugd/a95e8 6_524a61b9844b4d68ac48c2cf3e0fdd39.pdf

Network Waitangi Ōtautahi. (2018). Treaty of Waitangi questions and answers. Network Waitangi Ötautahi. https://nwo.org.nz/resources/questions-andanswers-booklet/

Orange, C. (2021). The Treaty of Waitangi Te Tiriti o Waitangi: An illustrated history. Bridget Williams Books. 
Peacock, C. (2017, November 29). Te reo on the radio too much for some. Mediawatch, Radio New Zealand.

https://www.radionz.co.nz/national/programmes/ mediawatch/audio/2018623484/te-reo-on-the-

radio-too-much-for-some

Pietikäinen, S. (2008). 'To breathe two airs'; Empowering indigenous Sami media. In P. Wilson \& M. Stewart (Eds.), Global indigenous media: Cultures, poetics, and politics (pp. 197-213). Duke University Press.

Pugh, A. J. (2013). What good are interviews for thinking about culture? Demystifying interpretive analysis. American Journal of Cultural Sociology, 1(1), 42-68. https://doi.org/10.1057/ajcs.2012.4

Ranford, J. (2015). 'Pakeha': Its origin and meaning. In ACE Papers Graduate Student Work-Issues in Contemporary Education, paper 8. University of Auckland.

https://maorinews.com/writings/papers/other/pa keha.htm

Reeves, J., \& Mathieson, M. (2015). Karanga: The first voice (series 1). Māori Television Service. https://www.maoritelevision.com/shows/karangafirst-voice

Rewi, P. (2010). Whaikōrero: The world of Māori oratory. Auckland University Press.

Roy, E. A. (2017, November 28). New Zealand broadcasters refuse to stop using Māori words. The Guardian.

http://www.theguardian.com/world/2017/nov/28 /new-zealand-broadcasters-refuse-to-stop-usingmaori-words

Salmond, A. (2004). Hui: A study of Mãori ceremonial gatherings ( $3^{\text {rd }}$ ed.). Penguin Group. 
Sheehan, M., \& Ball, G. (2020). Teaching and learning New Zealand's difficult histories. New Zealand Journal of History, 54(1), 51-68.

Sissons, H. (2016, June 9). Ethnographic multimodal discourse analysis. Communication Research Methods 2016: Practices and Challenges. ICA 2016 Preconference, Fukuoka, Japan.

Skogerbø, E., Josefsen, E., \& Fjellström, A.-M. (2019). Indigenous political journalism in the Norwegian and Swedish public service broadcasters. Journalism Studies, 20(7), 991-1008. https://doi.org/10.1080/1461670X.2018.1477550 Smith, L. T. (2012). Decolonizing methodologies: Research and indigenous peoples (2nd ed.). Otago University Press.

Stats NZ. (2020, September 23). Estimated resident population. https://www.stats.govt.nz/informationreleases/estimated-resident-population-2018-baseat-30-june-2018

Taaonga Tuku Iho. (2018). Te Hookioi, 67, 31-32.

Tauroa, H., \& Tauroa, P. (2009). Te Marae: A guide to customs \& protocol. Raupo.

Te Puni Kōkiri. (2018). Maihi karauna: The Crown's strategy for Maori language revitalisation 20182023. Consultation, August-September 2018. https://www.tpk.govt.nz/docs/tpk-maihikarauna-en-2018.pdf

Te Tira Whakaemi o Te Wairoa. (2014). Te Arawhiti: The Truth and Reconciliation Hui.

The Radio New Zealand Charter. (n.d.). https://www.radionz.co.nz/about/charter

Thompson, P. (2016, February 25). Next steps for RNZ's Māori strategy. Radio New Zealand. http://www.radionz.co.nz/news/te-manukorihi/297407/next-steps-for-rnz's-maori-strategy 
Tomoana, N. (2015, August 24). Ngahiwi Tomoana: Unity in strength: come together. New Zealand Herald. https://www.nzherald.co.nz

Waitangi Tribunal. (1999). The radio spectrum management and development final report (Wai 776). Waitangi Tribunal. https://forms.justice.govt.nz/search/WT/reports/ reportSummary.html?reportId=wt_DOC_68205950

Walter, R., \& Reilly, M. (2018). Ngā hekenga Waka: Migration and early settlement. In L. Carter, S. Duncan, G. Leoni, L. Paterson, M. Ratima, M. Reilly, \& P. Rewi (Eds.), Te Kōparapara: An introduction to the Māori world (pp. 67-86). Auckland University Press

Whelan, B. (2021). He whakangungu kairipoata nō Aotearoa: Journalism education of this place $[\mathrm{PhD}$ thesis, Auckland University of Technology]. https://openrepository.aut.ac.nz/handle/10292/1 $\underline{4340}$ 